\title{
COMPUTER SIMULATION OF THE VOLGA RIVER HYDROLOGICAL REGIME: PROBLEM OF WATER-RETAINING DAM OPTIMAL LOCATION
}

\author{
E.O. Agafonnikova, A.Yu. Klikunova, A.V. Khoperskov \\ Volgograd State University, Volgograd, Russian Federation \\ E-mail: agafonnikova@volsu.ru, klikunova@volsu.ru, khoperskov@volsu.ru
}

\begin{abstract}
We investigate of a special dam optimal location at the Volga river in the area of the Akhtuba left sleeve beginning $(7 \mathrm{~km}$ to the south of the Volga Hydroelectric Power Station dam). We claim that a new water-retaining dam can resolve the key problem of the VolgaAkhtuba floodplain related to insufficient water amount during spring floodings due to the overregulation of the Lower Volga. Using a numerical integration of Saint-Vanant equations we study the water dynamics across the northern part of the Volga-Akhtuba floodplain taking into account its actual topography. As the result we found an amount of water $V_{A}$ passing to the Akhtuba during spring period for a given water flow through the Volga Hydroelectric Power Station (so-called hydrograph which characterises the water flow per unit of time). By varying the location of the water-retaining dam $x_{d}, y_{d}$ we obtained various values of $V_{A}\left(x_{d}, y_{d}\right)$ as well as various flow spatial structure on the territory during the flood period. Gradient descent method provides the dam coordinated with the maximum value of $V_{A}$. Such approach to the dam location choice let us find the best solution, that the value $V_{A}$ increases by a factor of 2. Our analysis demonstrates a good potential of the numerical simulations in the field of hydraulic works.
\end{abstract}

Keywords: hydrodynamic simulation; Saint-Venant equations; numerical model; optimization; hydrology.

Introduction. The unique landscape of $20000 \mathrm{~km}^{2}$ Volga-Akhtuba floodplain (VAF) depends on special features of the interfluve hydrological regime. During the spring flood period the area between the Volga and Akhtuba rivers is heavily flooded [1-3], that ensures a special composition of flora and fauna and possibility of agricultural use of the area including the development of magnificent gardens and melon fields. The floodplain is also the basis for the fish reproduction at the Lower Volga region [4]. Nowadays the overregulation of the Volga-Kama basin hydrological regime by 22 Hydroelectric Power Plants leads to the VAP degradation.

Various approaches to the problem solution have beed proposed. Let us point out the attempts to construct so-called optimal hydrograph $Q(t)[5-7]$ which is close to the natural and ensures preservation of the natural rate. Despite the progress in the construction of the mathematical and hydrological regime control problems and the territory as a whole [8-11], there is a great difficulty of their practical implementation due to the conflict of various agents aspiration (energetics, environmental protection organizations, fish industry, agriculture, inhabitants, safety of reservoirs, etc.). Over the last decades the situation becomes even more complicated due to changes in the Volga riverbed below the dam mainly because of the violation of the spring flood natural process. In this study we discuss the possibility of the floodplain hydrological regime improvement by the construction of the water-retaining dam at the Volga riverbed close to the beginning of the Akhtuba left sleeve which is located approximately $7 \mathrm{~km}$ below the Volga Hydroelectric Power Station dam (Fig. 1). The main aim of the work is construction of a mathematical model for the 

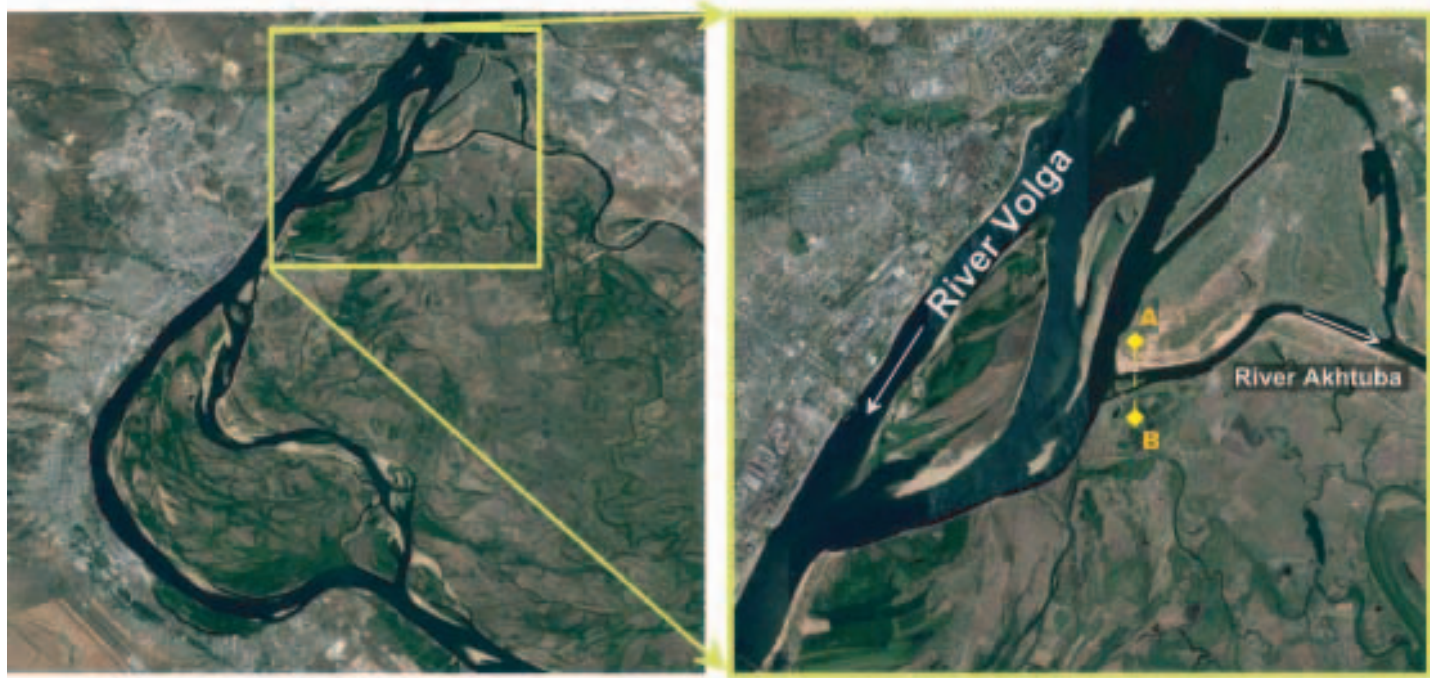

Fig. 1. The map of the northern part of the Volga-Akhtuba floodplain with the topography. The insert shows the part of the Volga with the Akhtuba springhead

estimation of the dam optimal location which provides the larger water flow rate in the Akhtuba during the spring flood.

1. The Hydrodynamic Model. At first, we briefly describe the hydrodynamic model underlying the base of our research. We use the Saint-Venant equations for the shallow water dynamics at a given topography $b(x, y)[1,9,12]$ :

$$
\begin{gathered}
\frac{\partial H}{\partial t}+\frac{\partial u H}{\partial x}+\frac{\partial v H}{\partial y}=\sigma(x, y, t), \\
\frac{\partial(u H)}{\partial t}+\frac{\partial\left(u^{2} H\right)}{\partial x}+\frac{\partial(u v H)}{\partial y}=-g H \frac{\partial(H+b)}{\partial x}+2 v H \Omega_{E} \sin (\theta)+f_{x}^{\text {fric }}+f_{\sigma x}, \\
\frac{\partial(v H)}{\partial t}+\frac{\partial(u v H)}{\partial x}+\frac{\left(v^{2} H\right)}{\partial y}=-g H \frac{\partial(H+b)}{\partial y}-2 u H \Omega_{E} \sin (\theta)+f_{y}^{\text {fric }}+f_{\sigma y},
\end{gathered}
$$

where $H$ is the water depth, $u$ and $v$ are the velocity of $x$-and $y$-components (averaged vertically), $\sigma$ is the source function, $g$ is referred to the gravitational acceleration, $\Omega_{E}$ is the Earth's angular velocity, $\theta$ is the latitude, the values of $f_{\sigma x}$ and $f_{\sigma y}$ describe the water impulse associated with the sources $\sigma$. For the bottom friction force vector we use the Chezy's model [1]:

$$
f_{x}^{\text {fric }}=-\frac{u}{2} \sqrt{u^{2}+v^{2}} H \Lambda, \quad f_{y}^{\text {fric }}=-\frac{v}{2} \sqrt{u^{2}+v^{2}} H \Lambda,
$$

with the value of hydraulic friction $\Lambda=2 g n_{M}^{2} / H^{4 / 3}$ and the Manning roughness coefficient $n_{M}$.

Value of $n_{M}$ is determined by the surface properties and generally it depends on the coordinates. Moreover, for the unsteady flow regime the Manning coefficient can vary with time [1]. The hydrograph through the Volga Hydroelectric Power Station dam allows to set the value of $\sigma=\frac{d Q_{0}}{d S}$ (where $d S=d x d y$ is an elementary area). Under the VAP conditions the value of $n_{M}$ for the Volga riverbed varies in the range $0,02-0,07$ [1].

For the numerical solution of equations (1) - (3) we apply our combined Lagrangian - Eulerian method (cSPH-TVD) [13] which uses the benefits of Smoothed Particle 
Hydrodynamics at different time steps and Total Variation Diminishing (see the detailed description in $[1,14])$.

The most important positive characteristics of the cSPH-TVD approach are the following:

- an adequate calculation of the dynamic boundaries between wet and dry beds in case of non-stationary fluxes through the strongly inhomogeneous bottom (even through the discontinuous topography);

- calculation for subcritical (with Froude number $F r=\sqrt{u^{2}+v^{2}} / \sqrt{g H}<1$ ) and supercritical $(F r>1)$ fluxes without isolation of these zones;

- numerical scheme of CSPH-TVD is conservative, well-balanced and has the second order of accuracy for smooth solutions the first order accuracy approximation in the vicinity of breaks and fracture profiles.

Both non steady solutions and strong heterogeneity of the topography require the specific boundary conditions formulation. Ref. [15] is dedicated to the application of the boundary conditions for the same aims by using the conditions of "waterfall" type, which we adopted in the current study.

The software implementation by using parallel technologies on graphics accelerators is presented in [12]. All basic calculations were performed on the GPU NVIDIA Tesla K80 [12]. We use Digital Elevation Models (DEM) with spatial resolution $\Delta x=\Delta y=$ $50 \mathrm{~m}$ and $25 \mathrm{~m}$, which is based on combination of several geodata: ASTER GDEM 2 (Global DIGITAL Elevation Model), SRTM X-SAR (Shuttle Radar Topography Mission) and Sentinel-1 SAR data, topographic data for coastlines of the hydrological system, our GPS / GLONASS measurements. To improve the model we use the sailing directions and special numerical hydrodynamical simulations allowing us to compare our results with observational data.

2. The Optimal Dam Location. For a given Volga Hydroelectric Power Station hydrograph $Q_{0}(t)$ we can calculate the water volume entering the Akhtuba during the spring flood (see Fig. 1):

$$
V_{A}=\int_{A}^{B} \int_{t_{Q s}}^{t_{Q e}} H(x, y, t)\left(u \cdot n_{x}+v \cdot n_{y}\right) d t d \ell,
$$

where the unit vector $\vec{n}=\left(n_{x}, n_{y}\right)$ is a normal to the Akhtuba river section line $(A, B)$ (see. Fig. $3 \mathrm{~b}$ ), $t_{Q s}$ and $t_{Q e}$ are the water release at beginning and final time, respectively (see. Fig. 2). Functions $H(x, y, t), u(x, y, t)$ and $v(x, y, t)$ are calculated by using the hydrodynamical model (1)-(3). We set up the dam of length $L_{d}$ at the Volga riverbed close to the Akhtuba springhead at the point $\left(x_{d}, y_{d}\right)$ (dam's center) which is perpendicular to the coastlines. The dam affects on the flow structure and on the value of $V_{A}$. For a given $L_{d}$ and $Q_{0}(t)$ we have function $V_{A}\left(x_{d}, y_{d}\right)$. We calculate the water-retaining dam optimal location for the specific riverbed area $S_{A}$ according to the following condition:

$$
V_{A}^{(\max )}=\max _{\left(x_{d}, y_{d}\right) \in S_{A}} V_{A}\left(x_{d}, y_{d}\right)
$$

$S_{A}$ is part of the Volga riverbed near the beginning of the Akhtuba (about $7 \mathrm{~km}$ downstream and $5 \mathrm{~km}$ upstream).

In Fig. 3 we show the $V_{A}^{(\max )}$ search procedure by using the gradient descent method:

$$
\vec{r}_{d}^{(k+1)}=\vec{r}_{d}^{(k)}+\lambda^{(k)} \operatorname{grad}\left(V_{A}\left(\vec{r}_{d}^{(k)}\right)\right) .
$$



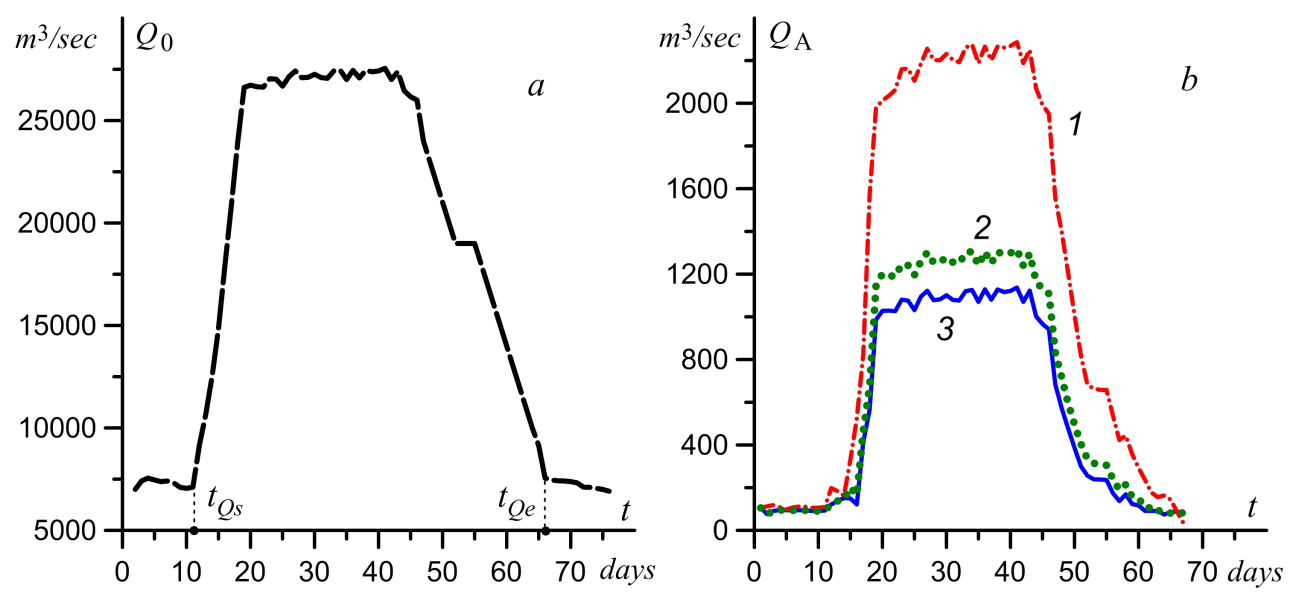

Fig. 2. The spring hydrograph $Q_{0}(t)$ of 2016 through the Volga Hydroelectric Power Station dam adopted in the model $(a)$. The hydrographs of Akhtuba $Q_{A}$ at different dam positions $(b): 1$ - the best dam position; 2 - without dam; 3 - the worst dam position

Finite difference approximation for the gradient calculation is used in the following form:

$$
\operatorname{grad}\left(V_{A}\left(\vec{r}_{d}\right)\right) \simeq\left\{\frac{V_{A}\left(x_{d}+\delta x, y_{d}\right)-V_{A}\left(x_{d}, y_{d}\right)}{\delta x} ; \frac{V_{A}\left(x_{d}, y_{d}+\delta y\right)-V_{A}\left(x_{d}, y_{d}\right)}{\delta y}\right\}
$$

on the meshgrid $x_{i+1}=x_{i}+\Delta x, y_{j+1}=y_{j}+\Delta y$. Our test numerical simulations demonstrated that the relations $\delta x=\delta y=2 \Delta x=2 \Delta y$ are reasonable choice.
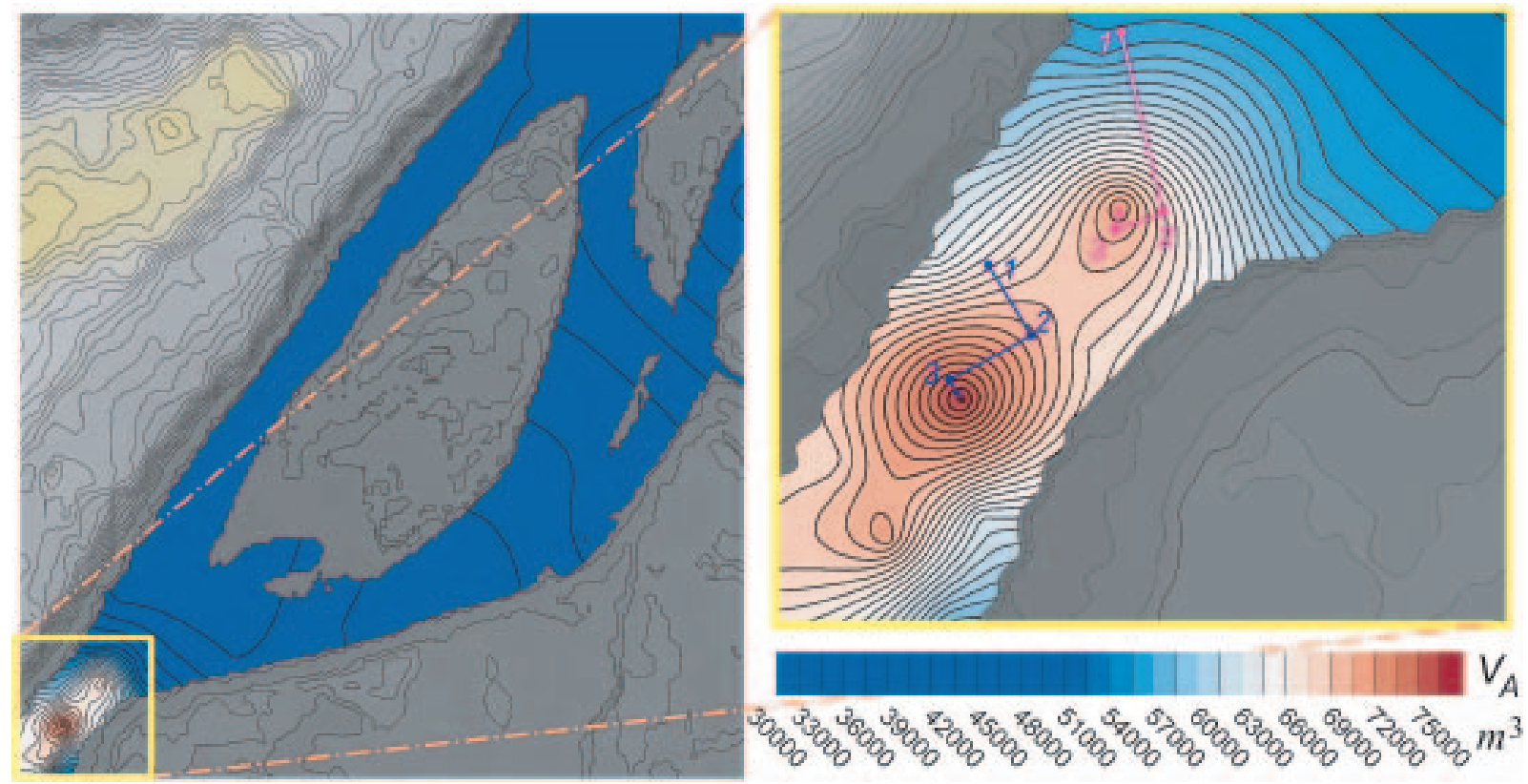

Fig. 3. The results of numerical hydrodynamical simulations for the function $V_{A}\left(x_{D}, y_{D}\right)$ and examples of the iterative procedure for the calculation of $V_{A}^{(\max )}$ in case of $L_{d}=300 \mathrm{~m}$

The symbols in Fig. $3 a$ indicate the positions of the iterative procedure (7), (8). The choice of $\lambda_{k}$ parameter and the convergence of calculations are achieved by using the steepest descent method. 
3. Results and Discussion. By means of numerical simulations we have studied the problem of the water-retaining dam location optimization at the Volga riverbed with the aim to increase the water amount at the left sleeve of the river Akhtuba. We summarize our results as following. There are several dam locations providing the appearance of the water volume local maximum $V_{A}$ in the Akhtuba during the spring flood. The positions $\left(x_{d m}^{(\max )}, y_{d m}^{(\max )}\right)(m=1,2,3)$ are located about $6 \mathrm{~km}$ downstream from the Akhtuba's beginning, that caused by the Volga riverbed structure at the area due to the large Volga width nearby the Akhtuba and large island (see Fig. 1). The best solution is $V_{A}^{(\max )}=$ $75000 \mathrm{~m}^{3}$. As a result, we can achieve a factor of 1,6 for maximum value of the hydrograph $Q_{A}(t)$ (see Fig. 2) and almost factor of 2 for $V_{A}$ from $V_{A 0}=43000 \mathrm{~m}^{3}$ up to $V_{A 0}=75000 \mathrm{~m}^{3}$ in comparison to the absence of the extra dam $\left(V_{A 0}=43000 \mathrm{~m}^{3}\right)$.

For a fixed set of free parameters any deviation of the dam orientation from the perpendicular relatively to the coastlines reduces the value $V_{A}$. The optimum location slightly depends on the dam size. It should be noted that there are some dam positions that determine the value of $V_{A}$ which is smaller than in the case of absence of the water-retaining dam. Our analysis is robust to small scale perturbations of the digital topography. A small variation of the function $b(x, y)$ conserve the approximate optimal solution $\left(x_{d}^{(\max )}, y_{d}^{(\max )}\right)$, but the issue still requires further investigation.

Acknowledgements. We are thankful to the Ministry of Education and Science of the Russian Federation (project 2.852.2017/4.6). The study was supported by the Supercomputing Center of Lomonosov Moscow State University. EOA is thankful to the RFBR (grants 16-07-01037, 15-45-02655).

\section{References}

1. Khrapov S., Pisarev A., Kobelev I., Zhumaliev A., Agafonnikova E., Losev A., Khoperskov A. The Numerical Simulation of Shallow Water: Estimation of the Roughness Coefficient on the Flood Stage. Advances in Mechanical Engineering, 2013, vol. 5, pp. 1-11. DOI: $10.1155 / 2013 / 787016$

2. Middelkoop H., Alabyan A.M., Babich D.B., Ivanov V.V. Post-Dam Channel and Floodplain Adjustment Along the Lower Volga River, Russia. Geomorphic Approaches to Integrated Floodplain Management of Lowland Fluvial Systems in North America and Europe. Springer, 2015, pp. 245-264. DOI: 10.1007/978-1-4939-2380-9_10

3. Ladjel M. Lamination Method of Flood Wadis and Projection of the Laminated Flood Hydrograph. Journal of Fundamental and Applied Sciences, 2016, vol. 8, no.1, pp. 83-91. DOI: $10.4314 /$ jfas.v8i1.6

4. Gorski K., van den Bosch L.V., van de Wolfshaar K.E., Middelkoop H., Nagelkerke L.A.J., Filippov O.V. et al. Post-Damming Flow Regime Development in a Large Lowland River (Volga, Russian Federation): Implications for Floodplain Inundation and Fisheries. River Research and Applications, 2012, vol. 28, no. 8, pp. 1121-1134. DOI: 10.1002/rra.1499.

5. Voronin A.A., Eliseeva M.V., Khrapov S.S., Pisarev A.V., Khoperskov A.V. [The Regimen Control Task in The Eco-Economic System "Volzhskaya Hydroelectric Power Station - the Volga-Akhtuba Floodplain". II. Synthesis of Control System]. Control Sciences, 2012, no. 6, pp. 19-25. (in Russian)

6. Chen D., Li R., Chen Q., Cai D. Deriving Optimal Daily Reservoir Operation Scheme with Consideration of Downstream Ecological Hydrograph Through a Time-Nested Approach. Water Resources Management, 2015, vol. 29, no. 9, pp. 3371-3386. DOI: 10.1007/s11269-015$1005-\mathrm{z}$ 
7. Haghighi A.T., Kløve B. Development of Monthly Optimal Flow Regimes for Allocated Environmental Flow Considering Natural Flow Regimes and Several Surface Water Protection Targets. Ecological Engineering, 2015, vol. 82, pp. 390-399. DOI: 10.1016/j.ecoleng.2015.05.035

8. Borsche R., Klar A. Flooding in Urban Drainage Systems: Coupling Hyperbolic Conservation Laws for Sewer Systems and Surface Flow. International Journal for Numerical Methods in Fluids, 2014, vol. 76, pp. 789-810. DOI: 10.1002/fld.3957

9. Voronin A.A., Vasilchenko A.A., Pisarev A.V., Khrapov S.S., Radchenko Yu.E. [Designing Mechanisms of the Hydrological Regime Management of the Volga-Akhtuba Floodplain Based on Geoinformation and Hydrodynamic Modelling]. Science Journal of Volgograd State University. Mathematics. Physics, 2016, no. 1 (32), pp. 24-37. DOI: 10.15688/jvolsu1.2016.1.3 (in Russian)

10. Izem N., Seaid M., Wakrim M. A Discontinuous Galerkin Method for Two-Layer Shallow Water Equations. Mathematics and Computers in Simulation, 2016, vol. 120, pp. 12-23. DOI: $10.1016 /$ j.matcom.2015.04.009

11. Bulatov O.V., Elizarova T.G. Regularized Shallow Water Equations for Numerical Simulation of Flows with a Moving Shoreline. Computational Mathematics and Mathematical Physics, 2016, vol. 56, no. 4, pp. 661-679. DOI: 10.1134/S0965542516040047

12. D'yakonova, T.A., Khoperskov A.V., Khrapov S.S. Numerical Model of Shallow Water: the Use of GPUs NVIDIA CUDA. Communications in Computer and Information Science, 2017, vol. 687 , pp. $132-145$.

13. Khrapov S.S., Khoperskov A.V., Kuz'min N.M., Pisarev A.V., Kobelev I.A. [A Numerical Scheme for Simulating the Dynamics of Surface Water on the Basis of the Combined SPHTVD Approach]. Numerical Methods and Programming, 2011, vol. 12, pp. 282-297. (in Russian)

14. Khrapov S.S., Kuzmin N.M., Butenko M.A. [The Comparison of Accuracy and Convergence for the CSPH-TVD Method and Some Eulerian Schemes for Solving Gas-Dynamic Equations]. Science Journal of Volgograd State University. Mathematics. Physics, 2016, no. 6 (37), pp. 166-173. DOI: 10.15688/jvolsu1.2016.6.15 (in Russian)

15. D'yakonova, T.A., Khrapov S.S., Khoperskov A.V. [The Problem of Boundary Conditions for the Shallow Water Equations]. Vestnik Udmurtskogo universiteta. Matematika. Mekhanika. Komp'yuternye nauki [The Bulletin of Udmurt University. Mathematics. Mechanics. Computer Science], 2016, vol. 26, no. 3, pp. 401-417. DOI: 10.20537/vm160309 (in Russian)

Received April 10, 2017

MSC 82D15, 76A20, 76M25

DOI: $10.14529 / \mathbf{m m p} 170313$

КОМПЬЮТЕРНОЕ МОДЕЛИРОВАНИЕ ГИДРОЛОГИЧЕСКОГО

РЕЖИМА ВОЛГИ: ЗАДАЧА ОПТИМАЛЬНОГО РАСПОЛОЖЕНИЯ ВОДОНАПОРНОЙ ДАМБЫ

\section{Е.О. Агафонникова, А.Ю. Кликунова, А.В. Хоперсков}

Волгоградский государственный университет, г. Волгоград

Рассмотрена задача оптимального расположения специальной дамбы в русле Волги в зоне начала ее левого рукава Ахтуба (7 км южнее плотины Волжской ГЭС). Новая 
водоподпорная дамба способна решить ключевую проблему Волго-Ахтубинской поймы, связанную с недостаточным объемом воды в период весеннего паводка из-за зарегулированности Нижней Волги. В основе математической модели расчета динамики воды лежит численное интегрирование нестационарных уравнений Сен-Венана для реального рельефа местности северной части Волго-Ахтубинской поймы. Результатом такого моделирования является расчет объема воды $V_{A}$, проходящий за весенний период в Ахтубу для определенного потока воды через гидроэлектростанцию (так называемый гидрограф характеризует объем воды, протекающей в единицу времени). Варьируя положение водоподпорной дамбы $x_{d}, y_{d}$, мы получаем различную структуру течения на территории в период паводка и различные значения $V_{A}\left(x_{d}, y_{d}\right)$. Использование метода градиентного спуска дает координаты дамбы с максимальным значением $V_{A}$. Такой подход к выбору положения дамбы позволяет рассчитать наиболее оптимальное решение, так что величина $V_{A}$ увеличивается примерно в 2 раза. Наше исследование демонстрирует большие возможности математического моделирования при проектировании такого рода гидросооружений.

Ключевые слова: гидродинамическое моделирование; уравнение Сен-Венана; численная модель; оптимизация; гидрология.

\section{Литература}

1. Khrapov, S. The Numerical Simulation of Shallow Water: Estimation of the Roughness Coefficient on the Flood Stage / S. Khrapov, A. Pisarev, I. Kobelev, A. Zhumaliev, E. Agafonnikova, A. Losev, A. Khoperskov // Advances in Mechanical Engineering. - 2013. - V. 5. - P. 1-11.

2. Middelkoop, H. Post-Dam Channel and Floodplain Adjustment Along the Lower Volga River, Russia / H. Middelkoop, A.M. Alabyan, D.B. Babich, V.V. Ivanov // Geomorphic Approaches to Integrated Floodplain Management of Lowland Fluvial Systems in North America and Europe. - 2015. - P. 245-264.

3. Ladjel, M. Lamination Method of Flood Wadis and Projection of the Laminated Flood Hydrograph / M. Ladjel // Journal of Fundamental and Applied Sciences. - 2016. - V. 8, № 1. - P. 83-91.

4. Gorski, K. Post-Damming Flow Regime Development in a Large Lowland River (Volga, Russian Federation): Implications for Floodplain Inundation and Fisheries / K. Gorski, L.V. van den Bosch, K.E. van de Wolfshaar et al. // River Research and Applications. 2012. - V. 28, № 8. - P. 1121-1134.

5. Задача управления гидрологическим режимом в эколого-экономической системе «Волжская ГЭС - Волго-Ахтубинская пойма». Ч. 2. Моделирование динамики поверхностных вод в период весеннего паводка / А.А. Воронин, М.В. Елисеева, С.С. Храпов, А.В. Писарев, А.В. Хоперсков // Проблемы управления. - 2012. - Т. 5, № 6. - С. 19-25.

6. Chen, D. Deriving Optimal Daily Reservoir Operation Scheme with Consideration of Downstream Ecological Hydrograph Through a Time-Nested Approach / D. Chen, R. Li, Q. Chen, D. Cai // Water Resources Management. - 2015. - V. 29, № 9. - P. 3371-3386.

7. Haghighi, A.T. Development of Monthly Optimal Flow Regimes for Allocated Environmental Flow Considering Natural Flow Regimes and Several Surface Water Protection Targets / A.T. Haghighi, B. Kløve // Ecological Engineering. - 2015. - V. 82. - P. 390-399.

8. Borsche, R. Flooding in Urban Drainage Systems: Coupling Hyperbolic Conservation Laws for Sewer Systems and Surface Flow / R. Borsche, A. Klar // International Journal for Numerical Methods in Fluids. - 2014. - V. 76. - P. 789-810. 
9. Воронин, А.А. Проектирование механизмов управления гидрологическим режимом Волго-Ахтубинской поймы на основе геоинформационного и гидродинамического моделирования / А.А. Воронин, А.А. Васильченко, А.В. Писарев, С.С. Храпов, Ю.Е. Радченко // Вестник Волгоградского государственного университета. Серия 1: Математика. Физика. - 2016. - № 1 (32). - С. 24-37.

10. Izem, N. A Discontinuous Galerkin Method for Two-Layer Shallow Water Equations N. Izem, M. Seaid, M. Wakrim // Mathematics and Computers in Simulation. - 2016. V. 120. - P. 12-23.

11. Bulatov, O.V. Regularized Shallow Water Equations for Numerical Simulation of Flows with a Moving Shoreline / O.V. Bulatov, T.G. Elizarova // Computational Mathematics and Mathematical Physics. - 2016. - V. 56, № 4. - P. 661-679.

12. D'yakonova, T.A. Numerical Model of Shallow Water: the Use of GPUs NVIDIA CUDA / T.A. D'yakonova, A.V. Khoperskov, S.S. Khrapov // Communications in Computer and Information Science. - 2017. - V. 687. - P. 132-145

13. Храпов, С.С. Численная схема для моделирования динамики поверхностных вод на основе комбинированного SPH-TVD подхода / C.C. Храпов, А.В. Хоперсков, Н.M. Кузьмин, А.В. Писарев, И.А. Кобелев // Вычислительные методы и программирование. - 2011. T. 12, № 2. - C. 282-297.

14. Храпов, C.C. Сравнение точности и сходимости для метода CSPH - TVD и некоторых эйлеровых схем для решения уравнения газодинамики / С.С. Храпов, Н.М. Кузьмин, М.А. Бутенко // Вестник Волгоградского государственного университета. Серия 1. Математика. Физика. - 2016. - № 6 (37). - С. 166-173.

15. Дьяконова, Т.А. Проблема граничных условий для уравнений мелкой воды / Т.А. Дьяконова, С.С. Храпов, А.В. Хоперсков // Вестник Удмуртского университета. Математика. Механика. Компьютерные науки. - 2016, - Т. 26, № 3. - С. 401-417.

Работа выполнена в рамках госзадания Министерства образования и науки РФ (проект № 2.852.2017/ПЧ).

Екатерина Олеговна Агафонникова, старший преподаватель, кафедра «Информационные системы и компьютерное моделирование», Волгоградский государственный университет (г. Волгоград, Российская Федерация), agafonnikova@volsu.ru.

Анна Юрьевна Кликунова, студент, кафедра «Информационные системы и компьютерное моделирование», Волгоградский государственный университет (г. Волгоград, Российская Федерация), klikunova@volsu.ru.

Александр Валентинович Хоперсков, доктор физико-математических наук, профессор, заведующий кафедрой «Информационные системы и компьютерное моделирование», Волгоградский государственный университет (г. Волгоград, Российская Федерация), khoperskov@volsu.ru.

Поступила в редакиию 10 апреля 2017 г. 